\section{AL-AZHAR}

Assiut Dental Journal
The Official Publication of The

Faculty of Dental medicine.

Al-Azhar Assiut Uniuersity.

Egypt

\title{
Evaluation of topically applied probiotic treatment on localized aggressive periodontitis patients: A split mouth study
}

\author{
Ibrahim Hammad Ibrahim*1, Ahmad Kassem Mohammad ${ }^{1}$, Mohamad Fouad Edrees ${ }^{1}$
}

Codex : 06/1901

Aadj@azhar.edu.eg

\section{KEYWORDS}

Gingiva, probiotic, periodontitis , scaling, root planning

1. Department of Oral Medicine, Periodontology, Diagnosis and Oral Radiology, Faculty of Dentistry, Al-Azhar University, Assiut

* Corresponding author e-mail: Ibrahimhammad.dent.ast.b@ azhar.edu.eg

\begin{abstract}
Aim: This study aims to evaluate clinically the effect of probiotic treatment on localized aggressive periodontitis patients. Subjects and methods: This study was designed as a randomized, controlled, split mouth clinical trial, carried out on localized aggressive periodontitis (LAP) which having almost two identical sites with clinical probing depth of $\geq 5 \mathrm{~mm}$. Two contralateral sites were randomly divided into two groups, Group I: received conventional periodontal treatment, scaling and root planning combined with topical application of probiotic. Group II: received conventional periodontal treatment, scaling and root planning only. Patients were evaluated clinically using the following parameters: plaque index (PI), gingival index (GI), probing pocket depth (PPD) and clinical attachment level (CAL) and radiographically by radiographic bone density (pixel) at baseline, 3, 6, and 9 months. Results: Clinical and radiographic results of this study showed that: there were a significant reduction for assessed variables (Plaque Index, gingival index, probing pocket depth and clinical attachment level and significant increase in radiographic bone density in probiotic group compared to group II. Conclusion: Adjunctive use of topically applied probiotic appeared to be beneficial effect in localized aggressive periodontitis patients when compared with scaling and root planning alone.
\end{abstract}

\section{INTRODUCTION}

Aggressive periodontitis has received considerable attention due to its peculiar clinical presentation, with a rapid attachment loss and bone destruction, with an apparent lack of the local factors, in patients with good oral hygiene. A variety of factors such as microbial, environmental, genetic, behavioral factors and systemic diseases have been suggested to influence the risk of aggressive periodontitis ${ }^{(1)}$.

Therapeutic treatments of aggressive periodontitis have based on removal of periodontopathogens from the subgingival area and worldwide-accepted strategies consist of scaling and root planning, which is considered as a gold standard treatment modality ${ }^{(2)}$. Although 
initially the number of pathogens can be greatly reduced by SRP, periodontopathogens quickly recolonize the treated niches in the oral cavity ${ }^{(3)}$.

Adjunctive use of local or systemic antimicrobials improves the outcome of periodontal therapy only temporarily. Thus, a life-long need for re-treatment arises, creating a serious socio-economic problem. Additionally, increasing levels of antibiotic resistant bacteria $^{(3)}$.

Beneficial, bacteria are important for maintaining a healthy subgingival ecosystem (4). and can affect disease progression in different ways: by "passively" occupying a niche which might otherwise be colonized by pathogens, by actively limiting a pathogen's ability to adhere to the appropriate tissue surfaces, by adversely affecting the vitality or growth of a pathogen, by affecting the ability of a pathogen to produce virulence factors, and/or by degrading virulence factors produced by the pathogen ${ }^{(5)}$.

The concept of periodontal replacement therapy consists of applying beneficial oral bacteria (Probiotic) subgingivally to prevent re-colonization of periodontal pockets by pathogens after scaling and root planning. This Guided Pocket Recolonization (GPR) approach may provide a valuable addition or alternative to the armamentarium of treatment options for periodontitis ${ }^{(2)}$.

\section{SUBJECTS AND METHODS}

This study was designed as a randomized, controlled, split mouth clinical trial, carried out on thirty patients (20 females and 10 males) aged (1826) years diagnosed clinically and radiographically as having localized aggressive periodontitis Fig (1) and two almost identical sites with clinical probing depth of $\geq 5 \mathrm{~mm}$ were selected. All eligible patients were thoroughly informed of the nature, potential risks and benefits of their participation in the study and signed their informed consent documents.

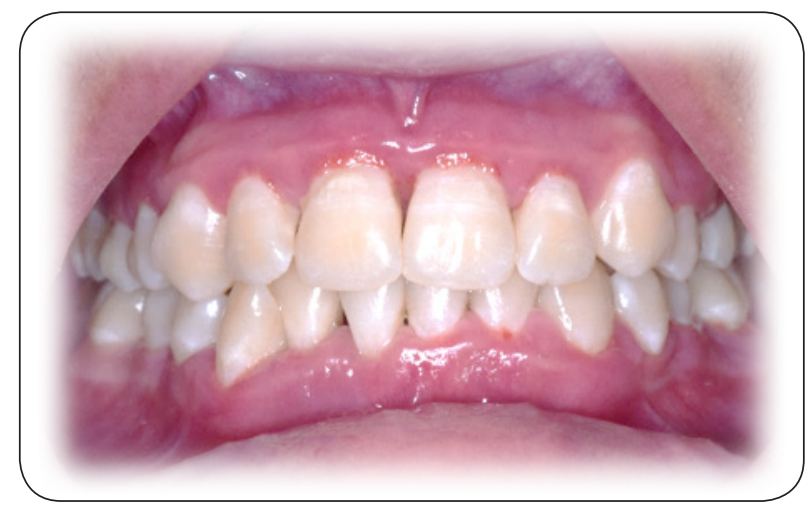

Fig (1-B): Panoramic radiograph of LAP case

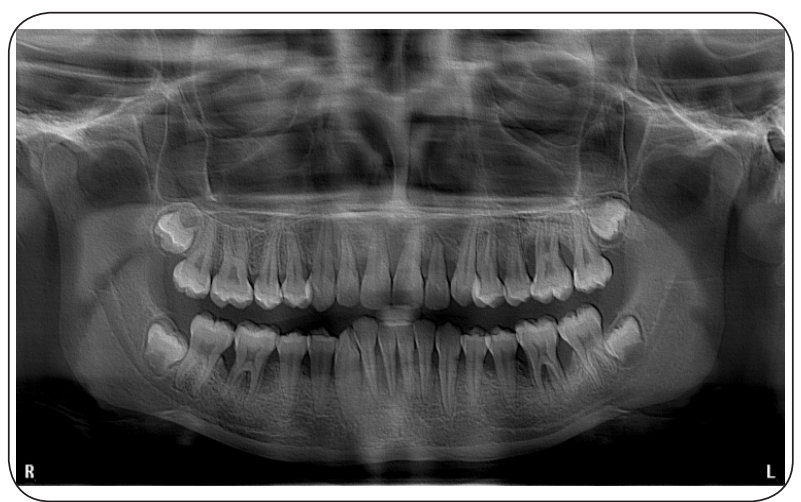

Fig (1-A): Clinical photos of LAP case

Two contralateral sites were randomly divided into two groups, random assignment was carried out by tossing coin ${ }^{(6)}$.

Group I: received conventional periodontal treatment, scaling and root planning combined with topical application of probiotic.

Group II: received conventional periodontal treatment, scaling and root planning only.

\section{Periodontal treatment:}

For both groups, thorough scaling and root planning was performed using hand instruments Hu-Friedy (Hu-Friedy, Chicago, USA), LM (LM dental, Porainen, Finland) Gracey curettes and scalers and EMS Mini Piezon (EMS, Switzerland) ultrasonic device under local anesthesia, when necessary. 
Probiotic preparation and application for the group I:

ProlacSan syringe (CMS Dental, Denmark) contains probiotic powder and thickener sealed in a metal foil. each syringe contains a total of $6 \times 10^{9}$ (CFU) of $L b$ brevis and $L b$ plantarum, to prepare, aspirate distilled water maximum $1.2 \mathrm{ml}$, shake and wait minimum 5 minutes.

The selected sites were isolated carefully with cotton rolls and thoroughly dried and the gel was applied carefully subgingivally until excess gel was observed from the gingival margin and excess gel was removed with a cotton roll. Fig (2) Patients were instructed not to eat, drink, or rinse for at least $30 \mathrm{~min}$, not to disturb the area with tongue, finger or toothpick, not to chew any hard, or sticky food for at least 1 week, postpone brushing and flossing on the treated site for 1 week.

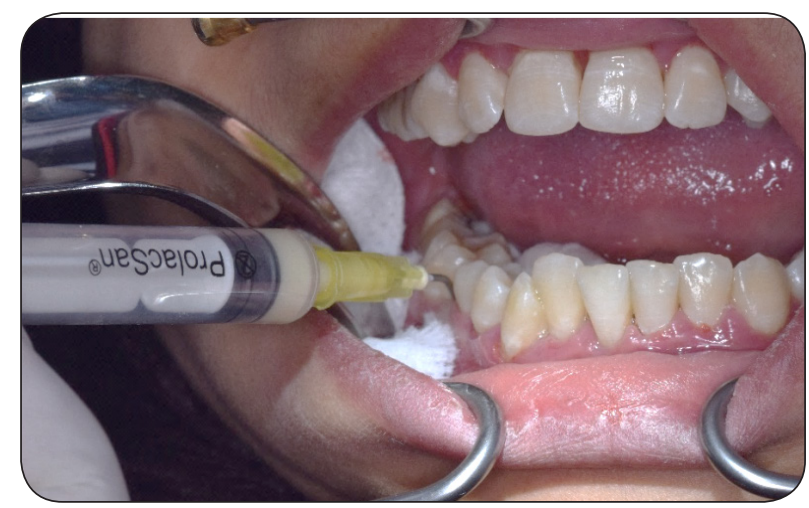

Fig (1-B): Panoramic radiograph of LAP case

Fig (2): Probiotic application

\section{Periodontal evaluation}

Patients were evaluated clinically at baseline, 3 , 6 , and 9 months post operatively using the following periodontal parameters:

(A)-Plaque Index $(\mathrm{PI})^{(7)}$, Gingival Index $(\mathrm{GI})^{(8)}$, Probing Depth (PD) ${ }^{(9)}$ and Clinical Attachment Level (CAL) ${ }^{(9)}$.

Probing depth and attachment level were measured using William's graduated periodontal probe (Hu-Friedy, Chicago, USA). To attain the reproducibility of the probing, a customized acrylic stent was used.

\section{Radiographic evaluation:}

Radiographic evaluation was done at baseline, 3, 6, and 9 months. A standardized periapical radiograph was taken using long cone parallel technique and customized bite block.

The exposure from $\mathrm{x}$ ray machine were received by image plate sensor size 2 that analyzed by the specific reader of vistascan (Durr Dental GmbH\& Co. Bietigheim- Bissingen, Germany) to produce the image that manipulated by BioQuant (Bioquant Image Analysis Corporation, Nashville, TN, USA). software analysis program to calculate bone density for region of interest (ROI) which range between 256 pixels for the most intense white (radiopaque) and 0 for the most intense black (radiolucent).

\section{RESULTS}

The clinical results of the current study showed that: In group I, there was highly statistically significant difference between means of plaque index scores at 3 and 6 months when compared to baseline and statistically significant difference at 9 month compared to the baseline and in In group II, there was statistically significant difference between means of plaque index scores at 3 month compared to baseline. Un-paired sample t-test showed no statistically significant difference between the two groups at different evaluation periods.

There was highly statistically significant difference between means of gingival index scores months in both groups compared to baseline at different evaluation periods. Un-paired sample t-test showed no statistically significant difference between the two groups at different evaluation periods.

There was highly statistically significant difference between means of probing pocket depth measurements at the different intervals compared to the baseline in both groups compared to the 
baseline Table. (1) Un-paired sample t-test showed no statistically significant difference in between two groups at different evaluation periods. Table (1)

There was highly statistically significant difference between means of clinical attachment level measurements at the different intervals compared to the baseline in both groups. Table (2) Un-paired sample t-test showed no statistically significant difference between the two groups at different evaluation periods. Table (2)
There was highly statistically significant difference between means of radiographic bone density at 6 and 9 months compared to the baseline in group I and there was no statistically significant difference between means of radiographic bone density at the different intervals compared to the baseline in group II. Table (3) Un-paired sample t-test showed no statistically significant difference between the two groups at different evaluation periods. Table (3)

Table (1): Mean $\pm S D$ values of Probing pocket depth (PPD) among studied groups at each evaluation period, along with significance level using paired \& unpaired t-test.

\begin{tabular}{|c|c|c|c|c|c|c|c|c|c|c|c|c|c|c|}
\hline \multirow{3}{*}{$\begin{array}{l}\text { FOLLOW UP } \\
\text { PERIODS } \\
\text { STUDIED } \\
\text { GROUPS }\end{array}$} & \multirow{2}{*}{\multicolumn{2}{|c|}{ BASELINE }} & \multirow{2}{*}{\multicolumn{2}{|c|}{$3 \mathrm{MONTH}$}} & \multirow{2}{*}{\multicolumn{2}{|c|}{$6 \mathrm{MONTH}$}} & \multirow{2}{*}{\multicolumn{2}{|c|}{$9 \mathrm{MONTH}$}} & $\begin{array}{r}3 \mathrm{MOI} \\
\mathrm{BAS}\end{array}$ & $\begin{array}{l}\text { TH VS } \\
\text { LINE }\end{array}$ & \multicolumn{2}{|c|}{$\begin{array}{l}6 \text { MONTH VS } \\
\text { BASELINE }\end{array}$} & \multicolumn{2}{|c|}{$\begin{array}{l}9 \text { MONTH VS } \\
\text { BASELINE }\end{array}$} \\
\hline & & & & & & & & & \multicolumn{6}{|c|}{ Paired t-Test } \\
\hline & \multicolumn{2}{|c|}{ Mean \pm SD } & \multicolumn{2}{|c|}{ Mean \pm SD } & \multicolumn{2}{|c|}{ Mean \pm SD } & \multicolumn{2}{|c|}{ Mean \pm SD } & $\mathrm{t}$ & $\mathrm{P}$ & $\mathrm{T}$ & $\mathrm{P}$ & $\mathrm{t}$ & $\mathrm{p}$ \\
\hline Group I & \multicolumn{2}{|c|}{$6.667 \pm 1.048$} & \multicolumn{2}{|c|}{$4.6 \pm 0.817$} & \multicolumn{2}{|c|}{$4.078 \pm 0.8136$} & \multicolumn{2}{|c|}{$3.578 \pm 1.463$} & 8.660 & $0.000 * *$ & 8.215 & $0.000 * *$ & 6.211 & $0.000 * *$ \\
\hline Group II & \multicolumn{2}{|c|}{$6.533 \pm 1.019$} & \multicolumn{2}{|c|}{$4.978 \pm 0.9324$} & \multicolumn{2}{|c|}{$4.422 \pm 0.9365$} & \multicolumn{2}{|c|}{$4.1 \pm 1.332$} & 12.460 & $0.000 * *$ & 9.646 & $0.000^{* *}$ & 5.619 & $0.000 * *$ \\
\hline \multicolumn{15}{|c|}{ Unpaired t-Test } \\
\hline & $\mathrm{T}$ & $\mathrm{P}$ & $\mathrm{T}$ & $\mathrm{P}$ & $\mathrm{T}$ & $\mathrm{P}$ & $\mathrm{T}$ & $\mathrm{P}$ & & & & & & \\
\hline GI I Vs G I & 0.273 & .394 & 0.914 & .187 & 0.833 & .209 & 0.792 & .220 & & & & & & \\
\hline
\end{tabular}

*Statistically significant: $(p<0.05)$.

Group I: scaling and root planning plus probiotics.
**High statistically significant: $(p<0.01)$.

Group II: scaling and root planning only

Table (2): Mean $\pm S D$ values of clinical attachment level among studied groups at each evaluation period, along with Significance level using paired \& unpaired t-test.

\begin{tabular}{|c|c|c|c|c|c|c|c|c|c|c|c|c|c|c|}
\hline \multirow{3}{*}{$\begin{array}{l}\text { FQLLOW UP } \\
\text { PERIODS } \\
\text { STUDIED } \\
\text { GROUPS }\end{array}$} & \multirow{2}{*}{\multicolumn{2}{|c|}{ BASELINE }} & \multirow{2}{*}{\multicolumn{2}{|c|}{$3 \mathrm{MONTH}$}} & \multirow{2}{*}{\multicolumn{2}{|c|}{$6 \mathrm{MONTH}$}} & \multirow{2}{*}{\multicolumn{2}{|c|}{9 MONTH }} & $\begin{array}{r}3 \mathrm{MO} \\
\mathrm{BAS}\end{array}$ & $\begin{array}{l}\text { TH VS } \\
\text { LINE }\end{array}$ & \multicolumn{2}{|c|}{$\begin{array}{l}6 \text { MONTH VS } \\
\text { BASELINE }\end{array}$} & \multicolumn{2}{|c|}{$\begin{array}{l}9 \text { MONTH VS } \\
\text { BASELINE }\end{array}$} \\
\hline & & & & & & & & & \multicolumn{6}{|c|}{ paired t-Test } \\
\hline & \multicolumn{2}{|c|}{ Mean \pm SD } & \multicolumn{2}{|c|}{ Mean \pm SD } & \multicolumn{2}{|c|}{ Mean \pm SD } & \multicolumn{2}{|c|}{ Mean \pm SD } & $\mathrm{t}$ & $\mathrm{p}$ & $\mathrm{T}$ & $\mathrm{P}$ & $\mathrm{t}$ & $\mathrm{p}$ \\
\hline Group I & \multicolumn{2}{|c|}{$5.7 \pm 0.6652$} & \multicolumn{2}{|c|}{$4.689 \pm 0.7167$} & \multicolumn{2}{|c|}{$4.356 \pm 0.7618$} & \multicolumn{2}{|c|}{$3.889 \pm 0.8328$} & 6.488 & $0.000 * *$ & 8.593 & $0.000 * *$ & 6.852 & $0.000 * *$ \\
\hline Group II & \multicolumn{2}{|c|}{$5.733 \pm 0.9912$} & \multicolumn{2}{|c|}{$5.011 \pm 0.8007$} & \multicolumn{2}{|c|}{$4.711 \pm 0.8223$} & \multicolumn{2}{|c|}{$4.478 \pm 1.022$} & 4.851 & $0.001 * *$ & 7.140 & $0.000 * *$ & 5.124 & $0.001 * *$ \\
\hline \multicolumn{9}{|c|}{ Unpaired t-Test } & & & & & & \\
\hline \multirow{2}{*}{ GII Vs G I } & $\mathrm{T}$ & $\mathrm{P}$ & $\mathrm{T}$ & $\mathrm{P}$ & $\mathrm{T}$ & $P$ & $\mathrm{~T}$ & $\mathrm{P}$ & & & & & & \\
\hline & 0.084 & .467 & 0.900 & .191 & 0.952 & .178 & 1.340 & .099 & & & & & & \\
\hline
\end{tabular}

*Statistically significant: $(p<0.05)$.

Group I: scaling and root planning plus probiotics.
**High statistically significant: $(p<0.01)$.

Group II: scaling and root planning only. 
Table (3): Mean $\pm S D$ values of Bone density (BD) pixels among studied groups at each evaluation period, along with significance level using paired \& unpaired t-test.

\begin{tabular}{|c|c|c|c|c|c|c|c|c|c|c|c|c|c|c|}
\hline \multirow{3}{*}{$\begin{array}{l}\text { FOLLOW UP } \\
\text { PERIODS } \\
\text { STUDIED } \\
\text { GROUPS }\end{array}$} & \multirow{2}{*}{\multicolumn{2}{|c|}{ BASELINE }} & \multirow{2}{*}{\multicolumn{2}{|c|}{$3 \mathrm{MONTH}$}} & \multirow{2}{*}{\multicolumn{2}{|c|}{$6 \mathrm{MONTH}$}} & \multirow{2}{*}{\multicolumn{2}{|c|}{$9 \mathrm{MONTH}$}} & \multicolumn{2}{|c|}{$\begin{array}{l}3 \text { MONTH VS } \\
\text { BASELINE }\end{array}$} & \multicolumn{2}{|c|}{$\begin{array}{l}6 \text { MONTH VS } \\
\text { BASELINE }\end{array}$} & \multicolumn{2}{|c|}{$\begin{array}{l}9 \text { MONTH VS } \\
\text { BASELINE }\end{array}$} \\
\hline & & & & & & & & & \multicolumn{6}{|c|}{ paired t-Test } \\
\hline & \multicolumn{2}{|c|}{ Mean \pm SD } & \multicolumn{2}{|c|}{ Mean \pm SD } & \multicolumn{2}{|c|}{ Mean \pm SD } & \multicolumn{2}{|c|}{ Mean \pm SD } & $\mathrm{t}$ & $\mathrm{P}$ & $\mathrm{t}$ & $\mathrm{P}$ & $\mathrm{t}$ & $\mathrm{p}$ \\
\hline Group I & \multicolumn{2}{|c|}{$80.11 \pm 10.46$} & \multicolumn{2}{|c|}{$81.22 \pm 11.21$} & \multicolumn{2}{|c|}{$88.33 \pm 13.29$} & \multicolumn{2}{|c|}{$92.33 \pm 14.53$} & 1.272 & 0.239 & 3.720 & $0.005^{* *}$ & 4.088 & $0.003 * *$ \\
\hline Group II & \multicolumn{2}{|c|}{$80.67 \pm 11.48$} & \multicolumn{2}{|c|}{$81.44 \pm 12.85$} & \multicolumn{2}{|c|}{$86.78 \pm 14.09$} & \multicolumn{2}{|c|}{$88.67 \pm 14.06$} & 0.642 & 0.538 & 2.242 & 0.055 & 2.255 & 0.054 \\
\hline \multicolumn{15}{|c|}{ Unpaired t-Test } \\
\hline & $\mathrm{T}$ & $\mathrm{P}$ & $\mathrm{T}$ & $\mathrm{P}$ & $\mathrm{T}$ & $P$ & $\mathrm{t}$ & $\mathrm{P}$ & & & & & & \\
\hline GI I Vs G I & 0.107 & .458 & 0.039 & .485 & 0.241 & .406 & 0.543 & .297 & & & & & & \\
\hline
\end{tabular}

*Statistically significant: $(p<0.05)$.

Group I: scaling and root planning plus probiotics.
**High statistically significant: $(p<0.01)$.

Group II: scaling and root planning only.

\section{DISCUSSION}

Aggressive periodontitis is a severe and rapidly destructive form of periodontitis, characterized by early onset, familial aggregation and affect individuals are otherwise clinically healthy. It is a multifactorial process results from a combination of genetic, environmental, host and microbial factors and present in a localized or generalized form.

In the present study patients with age ranged between (18-26), mean age of $(22.7 \pm 5.142)$ diagnosed as having LAP according to criteria of 1999 classification system proposed by American Academy of Periodontology ${ }^{(10)}$ were included.

this study was designed as a split mouth study which has the advantages of eliminating the inter individual variables However, it was stated that; the split-mouth design may lead to biased intervention effect estimates (underestimated or overestimated) due to carry-across effects which occurs when the treatment performed in one part of the mouth can affect the treatment responses in other parts. In this study a periodontal dressing was applied on the side of probiotic to minimize this effect. ${ }^{(11)}$

The probiotic used in this research contains a total of $6 \times 10^{9}$ (CFU) of two strain of Lactobacilli $(\mathrm{Lb})$ bacteria (Lb. brevis \& Lb. plantarum) which have the qualified presumption of safety (QPS) status from the European Food Safety Authorities (EFSA) ${ }^{(11,12)}$. In this study probiotic was used in the form of recently prepared topical (gel) formula applied subgingivally to the periodontal defect adjunctive to SRP for replacing or delay colonization of the pathogenic bacteria with beneficial bacteria. This concept was called "guided periodontal pocket recolonization (GBR)" (7).

Findings of this study indicated that there was a reduction in the plaque index scores in both group, and this reduction was statistically significant at different evaluation period in group I while in group II it was statistically significant only in 3 month when compared with base line. A reduction in the gingival index scores was found in both group and this reduction was highly statistically significant at different evaluation period in both group when compared with base line. Although these results are similar to findings of several studies ${ }^{(14-17)}$, another study found no statistically significant differences in gingival index between the groups at weeks after the intervention in a similar study ${ }^{(16)}$.

A reduction in probing pocket depth and clinical attachment level was recorded in this study in both groups after 9 month follow up and the reduction was highly statistically significant difference at the 
different intervals when compared to the baseline. This is in agreement with the results of a recent study evaluated the efficacy of local use of probiotic in the form of subgingival delivery and found that; adjunctive use of probiotics with scaling and root planing resulted in overall pocket depth reduction and clinical attachment gain ${ }^{(18)}$.

The results of this study showed that; the mean radiographic bone density were increasing in all follow up periods in both group and this was highly statistically significant difference at 6 and 9 months in group I, while there was no statistical significant group II when compared with base line. A similar result obtained by another study found there was a significant improvement in bone levels and bone density for the periodontal pockets treated with probiotics in comparison with the control group ${ }^{(19)}$.

\section{REFERENCES}

1. Piyush M, Sheela S,Gujjari K, Siddhpur V. Evaluation of the Effect of Probiotic (Inersan $\left.{ }^{\circledR}\right)$ Alone, Combination of Probiotic with Doxycycline and Doxycycline Alone on Aggressive Periodontitis -A Clinical and Microbiological Study. J Clin Diag Res. 2013; 7: 595-600.

2. Suchetha A, Apoorva S, Mundinamane D, Bhopale D, Bharwani A, Prasad R. An Insight into the Role of Benefical Bacteria in Periodontal Pocket Recolonization. J Oral Health Comm Dent. 2014; 8:47-50.

3. Teughels W, Newman M, Coucke W, Haffajee A, Van Der Mei H, Haake S, et al. Guiding periodontal pocket recolonization: a proof of concept. J Dent Res. 2007; 86: 107882 .

4. Roberts FA, Darveau RP. Beneficial bacteria of the periodontium. Periodontol 2000. 2002; 30:40-50.

5. 5. Teughels W, Loozen G, Quirynen M. Do probiotics offer opportunities to manipulate the periodontal oral microbiota? J Clin Periodontol. 2011; 38(Suppl 11):159-77.

6. Needleman I, Moles D, Worthington H. Evidence based periodontology, systematic reviews and research quality. Periodontol 2000. 2005; 37:12-28.

7. Silness J, Lo“e H. Periodontal disease in pregnancy II. Correlation between oral hygiene and periodontal condition. Acta Odontol Scand. 1964; 22:112-35.
8. Löe H, Silness J. Periodontal disease in pregnancy I. Prevalence and severity. Acta Odontol Scand.1963; 21:533-51.

9. Ramfjord S. The periodontal disease index (PDI) J Periodontol. 1967; 6:602-10.

10. Armitage G. Development of a classification system for periodontal diseases and conditions. Ann Periodontol. 1999; 4:1-6

11. Lesaffre E, Philstrom B, Needleman I and Worthington H. The design and analysis of split mouth studies: what statisticians and clinicians should know? Stat Med. 2009; 28: 3470-82.

12. European Food Safety Authority. Summary Report EFSA Scientific Colloquium 2. QPS: qualified presumption of safety of microorganisms in food and feed. Brussels, Belgium. 2004:1-142.

13. European Food Safety Authority. Scientific opinion on the maintenance of the list of QPS biological agents intentionally added to food and feed update. The EFSA J.2013; 11:1-108.

14. Krasse P, Carlsson B, Dahl C, Paulsson A, Nilsson A, Sinkiewicz G. Decreased gum bleeding and reduced gingivitis by the probiotic Lactobacillus reuteri. Swed Dent J. 2006; 30:55-60

15. Riccia DN, Bizzini F, Perilli MG, Polimeni A, Trinchieri $\mathrm{V}$, Amicosante G, et al. Anti-inflammatory effects of Lactobacillus brevis (CD2) on periodontal disease. Oral Dis. 2007; 13:376-85.

16. Shimauchi H, Mayanagi G, Nakaya S, Minamibuchi M, Ito Y, Yamaki K, et al. Improvement of periodontal condition by probiotics with Lactobacillus salivarius WB21: a randomized double blind placebo controlled study. J Clin Periodontol. 2008; 35: 897-905

17. Vivekananda M, Vandana K, Bhat K. Effect of the probiotic Lactobacilli reuteri (Prodentis) in the management of periodontal disease: a preliminary randomized clinical trial. J Oral Microbiol. 2010; 2:5344

18. Penala S, Kalakonda B, Pathakota KR, Jayakumar A, Koppolu P, Lakshmi BV, et al. Efficacy of local use of probiotics as an adjunct to scaling and root planing in chronic periodontitis and halitosis: A randomized controlled trial. J Res Pharm Pract. 2016; 5:86-93.

19. Nackerts O, Jacobs R, Quirynen M, Rober M. Replacement therapy for periodontitis: pilot radiographic evaluation in a dog model. J Clin Periodontol. 2008; 35:1048-52. 
مجلة أسيوط لطب الأسنان

النشر الرسمي لكلية طب الأسنان

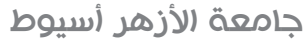

AADJ, Vol. 2, No. 1, April (2019) - PP. 57

الملخص العربي

الغرض من الدراسة:

أجريت هذه الدراسـة لتقييه التأثير الإكلينيكي للبروبيوتيك الموضعي في مـرضى التهاب النسـيج حـول الســي العدواني الموضعي

الموضوعات والأساليب:

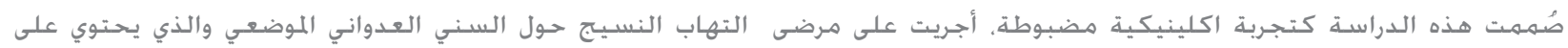

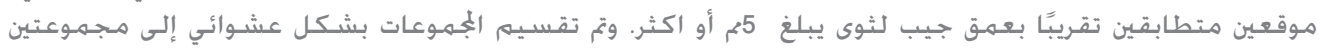
الججموعة الأولى: تلقيت العلاج اللثوي التقليدية ، كحت الجير وتسـويت الجذر جنبا إلى جنب مع التطبيق الموضعي للبروبيوتيك. الججموعة الثانية: تلقيت علاج اللثة التقليدي . كحت الجير وتسـويت الجذر فقط.

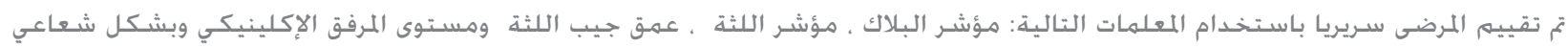

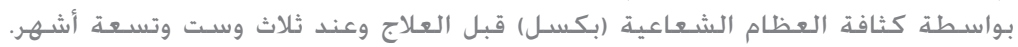

(النتائج:

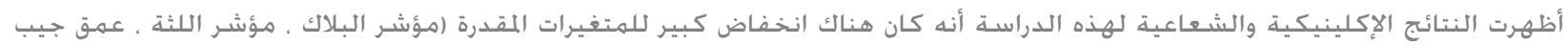

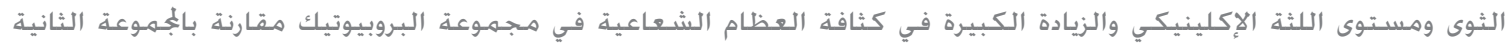

الخلاصة:

يبدو أن الاستخدام المساعد للبروبيوتيك موضعيا ذو تأثير مفيد في مرضى التهاب اللثة العدواني الموضعي بالمقارنة مع كحت الجير وتسـويت الجذر وحده 